\section{Endothelial nitric oxide synthase gene polymorphism and coronary heart disease in Japanese NIDDM}

Dear Sir,

Coronary heart disease (CHD) is one of the leading causes of death in Japan as well as in western countries. Many genes are suspected to be involved in its aetiology $[1,2]$. Most however, remain to be clarified. Nitric oxide (NO) has vasodilatation effects, and inhibits smooth muscle cell proliferation and platelet adhesion, which lead to the development of atherosclerosis [3]. Endothelial NO is formed from L-arginine by constitutively expressed endothelial NO synthase (ecNOS). Though the L-arginine-NO pathway has been implicated in contributing to the protection from developing CHD [4], an association of ecNOS gene mutations or polymorphisms with $\mathrm{CHD}$ had not been proved to exist. Several genetic variations in the ecNOS gene have been reported, however, scarcely any have been reported to be associated with cardiovascular diseases to our knowledge [5]. Recently, a 27-base pair (bp) repeat polymorphism in intron 4 of the ecNOS gene (ecNOS 4a/a genotype) was shown to be associated with a smoking-dependent risk of coronary artery disease [6]. This genotype was also associated with a history of myocardial infarction. These observations raise the possibility that this polymorphism is associated with CHD in noninsulin-dependent diabetes mellitus (NIDDM), which is a potent risk factor for the development of atherosclerosis and CHD besides smoking. We investigated 164 unrelated Japanese patients with NIDDM ( 89 males/75 females) to see whether this polymorphism is associated with CHD. Of these, 42 (22 males/20 females) had a past history of acute myocardial infarction or had angiographically proven CHD with more than $75 \%$ stenosis in at least one of the major coronary arteries (CHD + group), and 122 (67 males/55 females) who were apparently free from CHD on normal electrocardiograph at rest (CHD - group). Age (CHD +; mean $\pm \mathrm{SD} ; 63.7 \pm$ 8.8 years, CHD -: $61.8 \pm 7.7$ years: $p=0.17)$, sex $(p=0.78)$, body mass index $\left(26.3 \pm 4.2,24.8 \pm 4.0 \mathrm{~kg} / \mathrm{m}^{2}: p=0.053\right)$, duration of diabetes $(14.1 \pm 6.5,12.7 \pm 7.7$ years: $p=0.32)$, systolic $(152.0 \pm 25.3, \quad 144.0 \pm 25.7 \mathrm{~mm} \mathrm{Hg}: p=0.08)$ and diastolic (91.0 $\pm 14.4,86.1 \pm 13.3 \mathrm{~mm} \mathrm{Hg}: p=0.07)$ blood pressure, proportion of smokers $(0.24,0.25: p=0.93)$, serum total cholesterol $\quad(5.3 \pm 1.0, \quad 5.1 \pm 1.0 \mathrm{mmol} / \mathrm{l}: \quad p=0.16)$, triglycerides $(1.70 \pm 1.20, \quad 1.55 \pm 0.95 \mathrm{mmol} / \mathrm{l}: \quad$ Mann-Whitey's U-test, $p=0.56)$, Apo A1 $(1.34 \pm 0.28,1.37 \pm 0.26 \mathrm{~g} / \mathrm{l}: p=0.61)$, ApoB $(1.17 \pm 0.29, \quad 1.02 \pm 0.35 \mathrm{~g} / \mathrm{l}: \quad p=0.08), \quad \mathrm{HDL}$ cholesterol $(1.24 \pm 0.30, \quad 1.30 \pm 0.35 \mathrm{mmol} / \mathrm{l}: \quad p=0.57)$ and $\mathrm{HbA}_{1 \mathrm{c}}$ $(8.19 \pm 2.41,8.76 \pm 1.88 \%, p=0.61)$ were not significantly different statistically ( $t$-test) between the two groups.

The polymorphism was identified by polymerase chain reaction followed by electrophoresis on $6 \%$ polyacrylamide gel. The used primers were, sense primer: $5^{\prime}$-AGGCCCTATGGTAGTGCCTT-3' (5111-5130 bp), anti-sense: 5' $^{\prime}$ TCTCTTAGTGCTGTGGTCAC-3' (5530-5511 bp). Genetic determination (Table 1 ) revealed that among 42 CHD + patients, $31 \mathrm{had}$ b/b (insertion +/insertion + ) isoform and 11 had b/a (insertion +/insertion -) and none had a/a (insertion -/insertion -) isoform. Among $122 \mathrm{CHD}$ - patients, 103 patients $\mathrm{had} \mathrm{b} / \mathrm{b}$ isoform and 19 patients had $\mathrm{b} / \mathrm{a}$ and none had $\mathrm{a} / \mathrm{a}$ isoform. Neither the distribution of the ecNOS genotypes nor allele frequencies were significantly different between the $\mathrm{CHD}+$ and $\mathrm{CHD}$ - groups. A/a genotype, which is associated with CHD in Caucasians, proved to be rare in the analysed Japanese patients. From these observations, we conclude that 27-bp repeat polymorphism in intron 4 of ecNOS gene is unlikely to play a major role in the pathogenesis of $\mathrm{CHD}$ among Japanese patients with NIDDM. And rarity of a/a genotype may contribute to the low incidence of CHD in Japanese patients with NIDDM.

Yours sincerely.

M. Odawara, K. Sasaki, Y. Tachi, K. Yamashita

Table 1. Genotype and allele frequencies of the intron 4 deletion polymorphism of the endothelial nitric oxide synthase gene

\begin{tabular}{|c|c|c|c|c|c|c|c|c|c|c|}
\hline & \multicolumn{3}{|c|}{ Genotypes } & \multirow[t]{2}{*}{ Total } & \multirow[t]{2}{*}{ Chi-square } & \multirow[t]{2}{*}{$p$} & \multicolumn{2}{|c|}{ Allele } & \multirow[t]{2}{*}{ Total } & \multirow{2}{*}{$\begin{array}{l}\text { Fisher's } \\
p \text { value }\end{array}$} \\
\hline & $\mathrm{b} / \mathrm{b}$ & $\mathrm{b} / \mathrm{a}$ & $\mathrm{a} / \mathrm{a}$ & & & & $\mathrm{b}$ & $\mathrm{a}$ & & \\
\hline $\mathrm{CHD}+$ & $\begin{array}{c}31 \\
(73.8)\end{array}$ & $\begin{array}{c}11 \\
(26.2)\end{array}$ & $\begin{array}{c}0 \\
(0)\end{array}$ & $\begin{array}{c}42 \\
(100)\end{array}$ & 2.36 & 0.125 & 73 & 11 & 84 & 0.186 \\
\hline CHD - & $\begin{array}{l}103 \\
(84.4)\end{array}$ & $\begin{array}{l}19 \\
(15.6)\end{array}$ & $\begin{array}{c}0 \\
(0)\end{array}$ & $\begin{array}{c}122 \\
(100)\end{array}$ & & & 225 & 19 & 244 & \\
\hline
\end{tabular}

Data are n $(\%)$

Corresponding author: M.Odawara, M.D., The Wellcome Trust Centre for Human Genetics, University of Oxford, Windmill Road, Oxford, OX3 7BN, UK 


\section{References}

1. Odawara M, Matsunuma A, Yamashita K (1996) Platelet glycoprotein IIIa PIA polymorphism and Japanese diabetic patients with coronary heart disease. Lancet 348: 1310

2. Odawara M, Yamashita K (1997) Activated protein C resistance and Japanese NIDDM patients with coronary heart disease. Diabetes Care 20: 1339

3. Schmidt HHHW, Walter U (1994) NO at work. Cell 78: 919-925

4. Cooke JP, Singer AH, Tsao P, Zera P, Rowan RA, Billingham ME (1992) Antiatherogenic effects of L-arginine in the hypercholesterolemic rabbit. J Clin Invest 90: 11681172

5. Bonnrdeaux A, Nadaud S, Charru A, Jeunemaitre X, Corvol P, Soubrier F (1995) Lack of evidence for linkage of the endothelial cell nitric oxide synthase gene to essential hypertension. Circulation 91: 96-102

6. Wang XL, Sim AS, Badenhop RF, McCredie RM, Wilcken DEL (1996) A smoking-dependent risk of coronary artery disease associated with a polymorphism of the endothelial nitric oxide synthase gene. Nature Med 2: 41-45

\section{Identification of genetic markers to 20 NIDDM candidate genes by radiation hybrid analysis}

Dear Sir,

We have determined the fine chromosomal localization of 20 candidate genes for non-insulin-dependent diabetes (NIDDM) using radiation hybrid analysis [1] in an effort to identify short tandem repeat markers suitable for the genetic analysis of these genes in disease populations. Loci for which markers were identified include: leptin and its receptor, AMP kinase activated protein kinase, hexokinase II, pyruvate carboxylase, glutamine: fructose 6-phosphate amidotransferase (GFAT), islet regenerating protein, glucose 6-phosphatase, adrenoreceptors $\alpha 2 \mathrm{a}, \alpha 2 \mathrm{~b}$, and $\alpha 2 \mathrm{c}$, beta 3 adrenoceptor, liver mitochondrial carnitine palmitoyltransferase I, ras associated with diabetes (RAD), pancreatic polypeptide $\mathrm{Y}$, neuropeptide $\mathrm{Y}$ receptor 5, phenylethanolamine-N-methyltransferase, ATP citrate lyase, pyruvate dehydrogenase kinase 4 , and the agouti switch protein. Candidates were chosen because biochemical or physiological evidence suggests they play a role in aspects of metabolism which may be involved in the aetiology of NIDDM.

Primers to candidate genes were developed or otherwise obtained based upon published nucleotide sequences. Primers to GFAT were derived from partial genomic sequence obtained from a P1 clone DMPC-HFF\#1-802E1 (Genome Systems Inc., St. Louis, Mo. USA) identified by hybridization to GFAT cDNA consisting of bp 123-2168 of genbank accession number M90516. Primers to leptin were designed to amplify a CTTT tetranucleotide repeat contained within bp 4211-4477 of the gene (genbank accession number D63710). Primer sequences were LEPT1 5'-FAM-TCAACAAACCATTCTGAGTTC-3' and LEPT2 5'-TGGGACACATGTTCTCAGGA- $3^{\prime}$. The repeat was found to be highly informative in the 43 unrelated $\mathrm{CEPH}$ individuals genotyped (heterozygosity $=0.83$ ) and should thus serve as a good marker to genetically evaluate the contribution of leptin to human disease.

Primer pairs to these genes were then optimized for mapping onto the Stanford G3 and Genebridge GB4 radiation hy-

Corresponding author: M.J. Durcan, Ph. D., CNS Clinical Research, Glaxo Wellcome Inc, Five Moore Drive, PO Box 13398, Research Triangle Park, NC 27709-3398, USA brid panels (Research Genetics, Huntsville, Ala., USA). Marker retention data was analysed using RHMAP Version 2.01 for the G3 data or the Whitehead Institute-MIT Center for Genome Research radiation hybrid mapping web sever for the GB4 data. Distance relationships to nearby polymorphic markers were established using the statistical package RHMAPPER and RH2PT [2, 3].

Candidate gene markers in Table 1 are those with reported heterozygosities greater than $60 \%$ and estimated to be not more than two megabases $(\mathrm{Mb})(66.7$ centirays $[\mathrm{Cr}])$ from the candidate gene based on two-point analysis of Stanford G3 panel retention data. In about half of the cases, markers were determined to be within $1 \mathrm{Mb}(33.3 \mathrm{cR})$ of the gene. For some loci, approximate distances from markers had to be inferred by comparing both G3 and GB4 data because of gaps in the map data available from the European Bioinformatics Institute (EBI) [4]. In addition, a marker was nominated for a candidate gene only after one or more of the following conditions was met: 1) proximity to the marker was confirmed by an independent sequence tag site (STS) within the gene; 2) proximity to the marker was confirmed by an independent radiation hybridization ( $\mathrm{RH})$ panel; or 3 ) the candidate gene and nominated marker were part of a linkage group supported with a two-locus logarithm of odds (LOD) score of at least three using RH2PT.

Incorporation of NIDDM candidate gene markers, such as those reported here, within a genome scan will ensure that genes which play a role in insulin action, obesity, energy and glucose metabolism are evaluated for their role in genetic susceptibility to the disease. RH analysis offers a rapid and precise way to localize genes with respect to anonymous markers or other genes and thus offers an advantage over methods such as meiotic mapping or fluorescent in situ hybridization (FISH). Even when polymorphic markers are known to exist within the candidate gene, such as with RAD and hexokinase II, it is often desirable to identify other nearby markers that can be more conveniently included within a genome scan set or that are more informative in a particular study population. $\mathrm{RH}$ analysis offers a rapid method of identifying these markers.

Analysis of 20 NIDDM candidate genes by RH analysis has led to the identification of a polymorphic marker within $2 \mathrm{cM}$ $(\sim 2 \mathrm{Mb})$ of each gene. A highly informative marker to leptin has also been identified. These markers will prove to be important tools in the ongoing search for diabetes susceptibility loci.

Yours sincerely,

J. Rumberger, W. Gottschalk, D. Yarnall, Q. Nguyen, D. Burns, M. Durcan 